\title{
OPEN Modified Ziziphus spina-christi stones as green route for the removal of heavy metals
}

\author{
Eman A. Assirey ${ }^{1 凶}$, Shadia M. Sirry ${ }^{1}$, Hayfaa A. Burkani ${ }^{1}$ \& Medhat A. Ibrahim ${ }^{2 \bowtie}$
}

Green routes for remediation of heavy metals are worldwide challenges to overcome pollution problems on one hand and control the adverse impact of chemicals on the other hand. Biosorption is one of the most effective methods for removing lower level of heavy metals. The idea to apply natural resources as a green method for removal of heavy metals, this route has no adverse impacts on the environment. This study investigated the ability of chemically modified Ziziphus spina-christi stones (ZSCs) as agriculture by-products to perform the biosorption of $\mathrm{Pb}(\mathrm{II}), \mathrm{Zn}(\mathrm{II})$ and $\mathrm{Cd}(\mathrm{II})$ ions from wastewater in a single and ternary metal system. The characteristic functional groups of chemically modified ZSCs were analyzed by Fourier transform infrared. In comparison with acidic ZSCs, alkalimodified ZSCs by KOH was more effective and enhanced the removal efficiency of ZSCs. Using Langmuir isotherm, the maximum adsorption capacity on the modified ZSCs for $\mathrm{Pb}$ (II) was $9.06 \mathrm{mg} / \mathrm{g}$, for Zn(II) obtained by using ZSC-citric acid was $4.19 \mathrm{mg} / \mathrm{g}$ and $5.38 \mathrm{mg} / \mathrm{g}$ for Cd(II) as obtained by using $\mathrm{ZSC}-\mathrm{H}_{2} \mathrm{O}_{2}$. The molecular electrostatic potential, which was calculated at $\mathrm{B} 3 \mathrm{LYP} / 6-31 \mathrm{G}(\mathrm{d}, \mathrm{p})$, indicated that each metal is di-hydrated, forming a complex with two units of amino acids. This mechanism demonstrated the uptake process by ZSCs.

Different man-made activities with continuous effluents are considered among the main source for the contamination of aquatic ecosystems ${ }^{1,2}$. One of the most common constituents of these effluents the heavy metals (HMs). HMs are of growing concern, according to their accumulative and toxicity for aquatic system ${ }^{3,4}$. Many researchers applying different routes to control the level of HMs in the environment. Recently, a special interest has been devoted to the use of natural sorbents as an alternative to the traditional ones ${ }^{5}$. Biological substances have an affinity for organic and inorganic pollutants, meaning that there is enormous potential for biosorption within countless kinds of biomaterials. The high affinity of biosorbents towards metal ions is owed to their surface chemistry, which consists of many reactive functional groups characterized by their unique hydrogen bonding, which is the effective tool for remediation heavy metals from wastewater ${ }^{6,7}$. These functional groups are capable of binding heavy metal ions by the substitution of a hydrogen bonding with the existing metal in solution, or by the formation of metal ion-complexes through the hydrogen bond of the functional group with the given metal ions ${ }^{6-9}$. Ziziphus spina-christi refers to trees in the Rhamnaceae family; generally, in Arabic countries, the tree is called sidr and its fruit is known as nabag ${ }^{10}$. Its fruits, leaves, bark and roots in are used in medicine owing to their many benefits ${ }^{11}$. ZSCs contain protein, crude fat, fibers, carbohydrate, sugar, macro elements (potassium, calcium, sodium and magnesium), and trace elements such as copper and manganese, making the stones nontoxic ${ }^{12-14}$. Utilizing raw plant wastes as biosorbents can cause a low adsorption capacity ${ }^{15}$; however, biosorbent performance can be enhanced with several types of physical and chemical modifications ${ }^{16}$. The main reasons for the modification of raw biosorbents are to improve the biosorbent's resistance toward chemical and microbial degradation, biosorption selectivity, the removal of impurities, and the increase of the metal ion biosorption capacity ${ }^{17,18}$. Physical modification includes the appropriate sizing of the biosorbents by chopping and grinding, heat treatment (steaming and drying), ultrasonic treatment, stirring, freeze drying (lyophilization), and autoclaving ${ }^{19}$. Physical modification is inexpensive and simple, but it is less efficient than chemical modification ${ }^{17,18}$. Great improvements in the biosorption capacity can be achieved by the chemical modification of functional groups on the biosorbent surface ${ }^{20}$. Chemical modifications include the treatment of the biosorbents via chemical agents for washing, increasing the binding groups, the elimination of inhibiting groups and by covering the biosorbent with ionic polymers ${ }^{21}$. Several types of modifying agents can be used for the modification processes such as acid solutions (sulfuric acid) ${ }^{22}$, hydrochloric acid ${ }^{23}$, nitric acid ${ }^{24}$, base

${ }^{1}$ Chemistry Department, Taibah University, Madinah 30002, Saudi Arabia. ${ }^{2}$ Molecular Spectroscopy and Modeling Unit, Spectroscopy Department, National Research Centre, El-Bohouth Str., 12622 Dokki, Giza, Egypt. ${ }^{\circledR}$ email: eman_assirey@hotmail.com; medahmed6@yahoo.com 
solutions (sodium hydroxide, sodium carbonate) ${ }^{25}$, organic compounds (formaldehyde) ${ }^{26}$, and oxidizing agents (hydrogen peroxide $)^{27}$. Increasing the binding groups involves the substitution of specific functional groups on the biosorbent's surface with desirable functional groups by various chemical modification methods, such as the amination of giving functional groups, carboxylation of hydroxyl and amine groups, phosphorylation of hydroxyl groups, saponification of ester groups, halogenation and oxidation. Raw biosorbents comprise several functional groups, and only certain groups are responsible for targeting metal ions, while the other groups could interfere with the metal ions. Hence, the elimination of inhibiting groups is important for enhancing biosorption, and usually involves decarboxylation and deamination ${ }^{18,19,21}$.

Molecular modeling has recently shown potential application as promising tool describing the molecular interactions in many systems $\mathrm{s}^{28-30}$. Especially those dealing with environmental interactions ${ }^{31,32}$. This paves the way toward, applying molecular modeling to investigating the mechanism of interaction between heavy metals and modified ZSCs.

Therefore, the present work is conducted in order to enhance the capacity of a green route based on natural material (ZSCs) which modified by different chemical modifying agents for the biosorption of $\mathrm{Pb}$ (II), $\mathrm{Zn}$ (II) and $\mathrm{Cd}(\mathrm{II})$ ions from aqueous solution in single and ternary metal systems. Isotherm models are used for the determination of their maximum sorption capacities. The active sites of interaction are indicated in terms of the electrostatic potential (ESP) and studied with the B3LYP/6-31G(d,p) molecular modeling approach.

\section{Materials and method}

Materials and chemicals. ZSCs were collected from Al-Madinah Al-Munawwarah fruit market. The metal salts including cadmium (II) nitrate $\left(\mathrm{Cd}\left(\mathrm{NO}_{3}\right)_{2} \cdot 4 \mathrm{H}_{2} \mathrm{O}\right)$, lead (II) nitrate $\left(\mathrm{Pb}\left(\mathrm{NO}_{3}\right)_{2}\right)$ and zinc nitrate $\mathrm{Zn}\left(\mathrm{NO}_{3}\right)_{2} \cdot 6 \mathrm{H}_{2} \mathrm{O}$ used for the preparation of a stock solution of metals were purchased from Sigma-Aldrich [St Louis, MO, USA]. Sodium nitrate $\left(\mathrm{NaNO}_{3}\right)$ (Sigma-Aldrich) was used for the adjustment of the ionic strength. Sodium acetate trihydrate $\left(\mathrm{C}_{2} \mathrm{H}_{3} \mathrm{NaO}_{2} .3 \mathrm{H}_{2} \mathrm{O}\right)$ and acetic acid from Sigma-Aldrich were used for buffer preparation. Potassium hydroxide $(\mathrm{KOH})$, hydrochloric acid (HCL), sulfuric acid $\left(\mathrm{H}_{2} \mathrm{SO}_{4}\right)$ (Sigma-Aldrich), anhydrous citric acid $\left(\mathrm{C}_{6} \mathrm{H}_{8} \mathrm{O}_{7}\right)$ (FlukaBioChemika) and hydrogen peroxide $\left(\mathrm{H}_{2} \mathrm{O}_{2}\right)$ (Sigma-Aldrich) were used as modifying agents for the biosorbent.

Preparation of modified ZSCs. ZSCs particles of size $250 \mu \mathrm{m}$ were prepared following the previous procedure which was reported earlier ${ }^{33}$. They were chemically modified by treatment with $0.5 \mathrm{M}$ hydrochloric acid, $0.5 \mathrm{M}$ citric acid, $0.5 \mathrm{M}$ sulfuric acid, $0.5 \mathrm{M}$ potassium hydroxide, and $1 \mathrm{M}$ hydrogen peroxide. $10 \mathrm{~g}$ of stone particles was shaken with $250 \mathrm{~mL}$ of the modifying solution at $300 \mathrm{rpm}$ for two hours. ZSCs were then filtered and washed several times with distilled water using a decantation process until the $\mathrm{pH}$ of the solution was equal to the $\mathrm{pH}$ of the distilled water. ZSCs were then left to dry in the air, then finally stored in a glass bottle in the desiccator.

Batch experiment. The experimental conditions which applied in this work, including some factors, such as the initial metal ion concentration, $\mathrm{pH}$, contact time, and dose of the sorbent, were studied by batch experiment. All experiments were carried out using a series of $25 \mathrm{~mL}$ solutions containing an appropriate amount of each desired metal ion, buffer solutions, $0.1 \mathrm{M}$ sodium nitrate solution and an adequate amount of $250 \mu \mathrm{m}$ pore size ZSCs. These solutions were shaken using a digital orbital shaker at $300 \mathrm{rpm}$ at different time intervals. The $\mathrm{pH}$ was adjusted using acetate buffer. The solution was filtered, and the metal ion concentration was determined according to the American Public Health Association (APHA) standard methods, $2017^{34}$, using inductively coupled plasma optical emission spectroscopy (ICP-OES). Each recorded reading is a sum of five replicates. The amount of adsorbed metal ions per gram of ZSCs at equilibrium $q_{e}(\mathrm{mg} / \mathrm{g})$ and the removal percentage (\% removal) was calculated using Eqs. (3) and (4):

$$
\begin{gathered}
q_{e}=\frac{\left(C_{0}-C_{\mathrm{e}}\right) \cdot V}{m} \\
\text { \%Removal }=\frac{C_{0}-C_{e}}{C_{0}} \times 100
\end{gathered}
$$

where $C_{0}$ and $C_{e}$ are the initial and equilibrium metal ion concentration $\left(\mathrm{mg} \mathrm{L}^{-1}\right)$, respectively, $V$ is the volume of metal ion solution (L) and $\mathrm{m}$ is the weight of adsorbent $(\mathrm{g})$.

Fourier transform infrared (FTIR) ANALYSIS. FTIR spectra were acquired in transmission mode using Bruker, Vertex 70, FTIR spectrometer. Spectra were recorded in the spectral region of $4000-400 \mathrm{~cm}^{-1}$ with $4 \mathrm{~cm}^{-1}$ spectral resolution and 000 co-added scans.

Langmuir isotherm. The Langmuir isotherm is the best model for describing the biosorption equilibrium between the metal ion solution and the sorbents (solid phase). It is used to obtain the maximum adsorption capacity related to complete monolayer coverage on the homogeneous surface of the sorbent ${ }^{22}$. The Langmuir equation is given by the following:

$$
q_{e}=\frac{q_{\max } K_{L} C_{e}}{1+K_{L} C_{e}}
$$




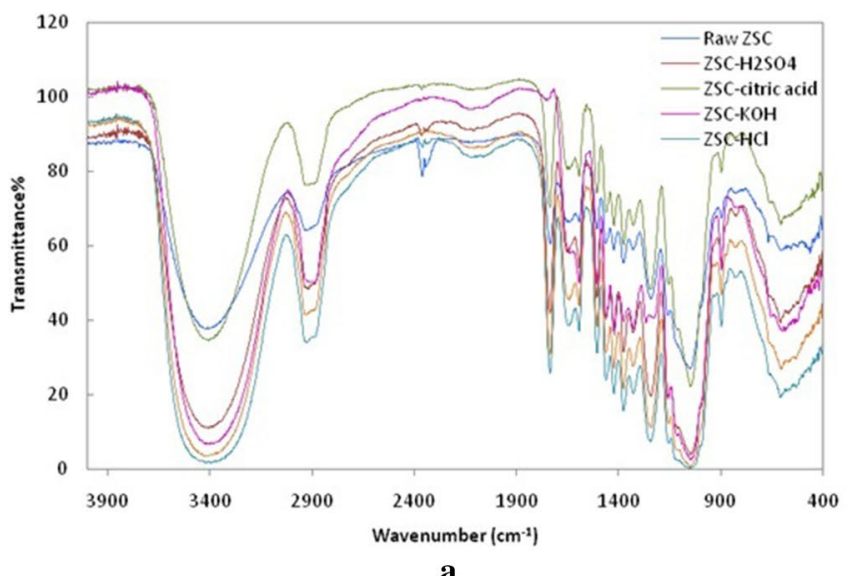

a

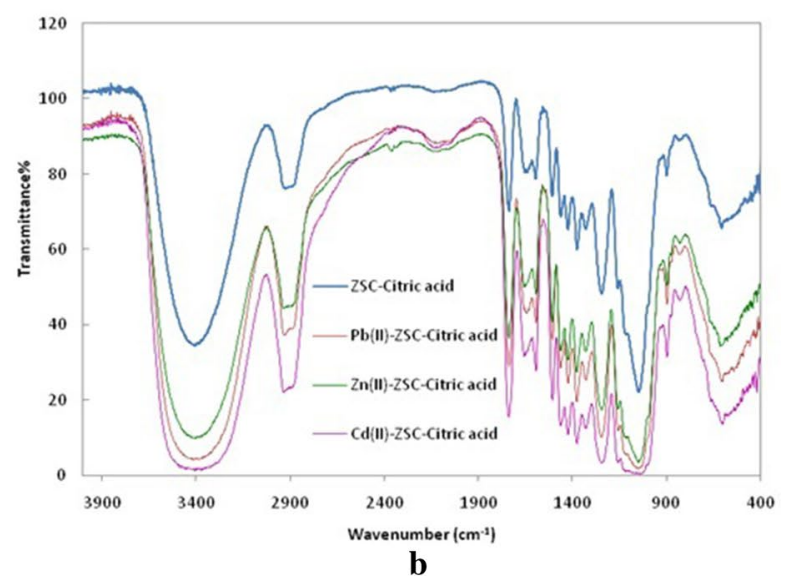

b

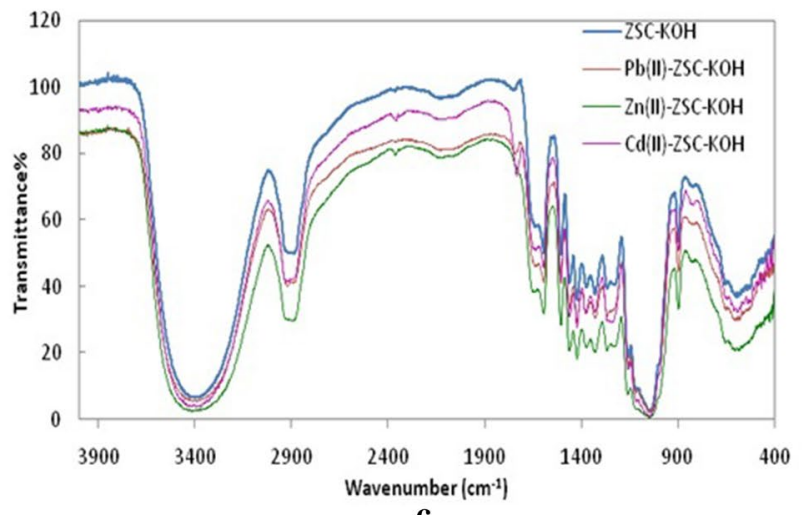

c

Figure 1. FTIR spectroscopy for (a) samples of the raw and chemically modified ZSCs, (b) for samples after $\mathrm{Pb}(\mathrm{II}), \mathrm{Zn}(\mathrm{II})$ and $\mathrm{Cd}(\mathrm{II})$ ion biosorption by ZSC-citric acid, (c) samples after $\mathrm{Pb}(\mathrm{II}), \mathrm{Zn}(\mathrm{II})$ and $\mathrm{Cd}(\mathrm{II})$ ion biosorption by ZSC-KOH.

where $q_{e}(\mathrm{mg} / \mathrm{g})$ is the amount of adsorbed metal ions per gram of sorbent at equilibrium, $q_{\text {max }}$ is the maximum adsorption capacity, $K_{L}(\mathrm{~L} / \mathrm{g})$ is the Langmuir constant, which refers to the energy of the adsorption/desorption process, and $C_{e}$ is the equilibrium metal ion concentration $(\mathrm{mg} / \mathrm{L})^{35,36}$.

Calculation details. All the studied structures were subjected to optimization with G09 program at Spectroscopy Department, National Research Centre, Egypt ${ }^{37}$. B3LYP/6-31 g(d,p) model ${ }^{38-40}$ was used in the calculations. The molecular ESP was calculated at the same level of theory as a test for the reactivity of the studied structures.

\section{Results and discussion}

Characterization of the biosorbent. Fourier transform infrared analysis (FTIR). FTIR analysis was applied to raw and chemically modified ZSCs in order to characterize the chemical functional groups that are responsible for the removal process.

The FTIR spectra of chemically modified ZSCs are shown in Fig. 1. ZSCs modified by diluting acid solutions indicated only a partial modification of their functional group properties. The main bands of raw ZSCs are preserved with slight changes in the intensities of these bands. All acidic-modified ZSCs showed an increase in the broadening of the $\mathrm{O}-\mathrm{H}$ group at $3356 \mathrm{~cm}^{-1}$ with a slight shift indicating the increase in carboxylic O-H groups $^{41}$. An increase in the intensity of the $\mathrm{C}=\mathrm{O}$ band at $1730 \mathrm{~cm}^{-1}$ also indicated the increase in carboxylic groups. In addition, there was some increase in the intensity of the bands at $1035-1134 \mathrm{~cm}^{-1}$, demonstrating an increase in the functional groups of $\mathrm{C}-\mathrm{O}$ stretching vibrations such as ethers and phenols ${ }^{42}$. The FTIR spectra of ZSCs chemically modified by diluting alkali solution showed a shift of the $\mathrm{C}=\mathrm{O}$ band $\left(1730 \mathrm{~cm}^{-1}\right)$ and slight shifting of the band of carboxylate ion $\left(1610 \mathrm{~cm}^{-1}\right)$ and the band of the $\mathrm{O}-\mathrm{H}$ group $\left(3356 \mathrm{~cm}^{-1}\right)$ to lower wavenumbers due to the hydrolysis of ester groups, which subsequently increased the carboxylate groups and $\mathrm{O}-\mathrm{H}$ group $^{43}$. It is also noted that the $\mathrm{C}-\mathrm{O}$ band intensity $\left(\right.$ at $\left.1230 \mathrm{~cm}^{-1}\right)$ decreased, indicating the removal of waxes by the alkali treatment ${ }^{44,45}$. In the case of citric acid modification, an esterification reaction may have occurred due to the shift of the band at $3356 \mathrm{~cm}^{-1}$ to $3340 \mathrm{~cm}^{-1}$ and the sharpening of the band at $1730 \mathrm{~cm}^{-146,47}$. Hydrogen peroxide modification shows an increase in the intensity of the bands at $1730 \mathrm{~cm}^{-1}$ and $1035 \mathrm{~cm}^{-1}$, indicating partial oxidation of $\mathrm{C}=\mathrm{O}$ and $\mathrm{C}-\mathrm{O}$ functional groups ${ }^{48}$.

Figure 1a-c present the FTIR spectroscopy for raw samples as well as other samples after metals biosorption. The differences observed in the spectra after metal ion biosorption, as shown in Fig. 1 b,c, were around 1035, 


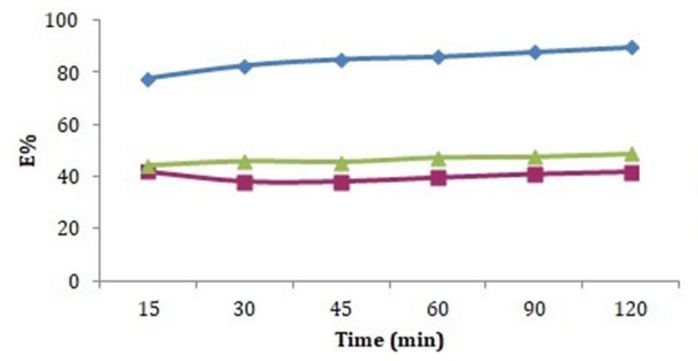

a

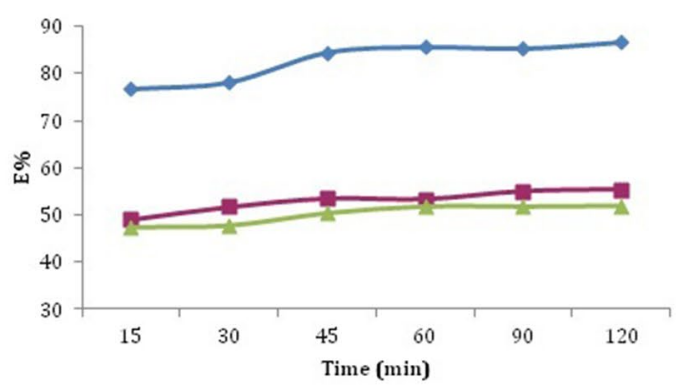

c

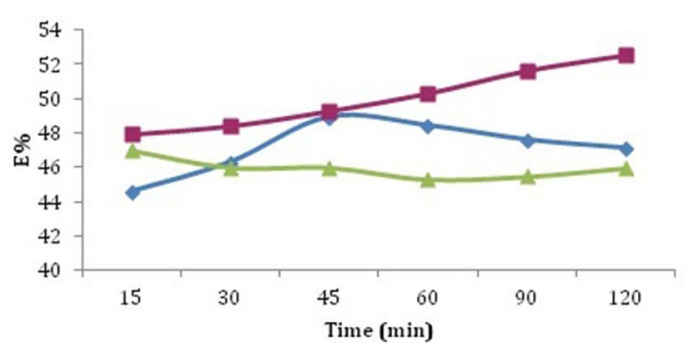

e
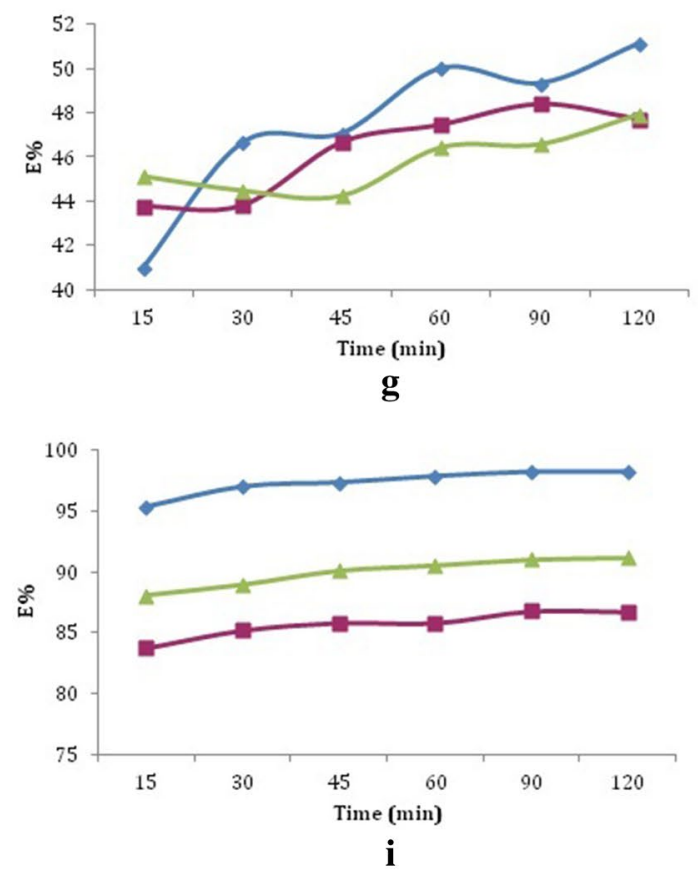
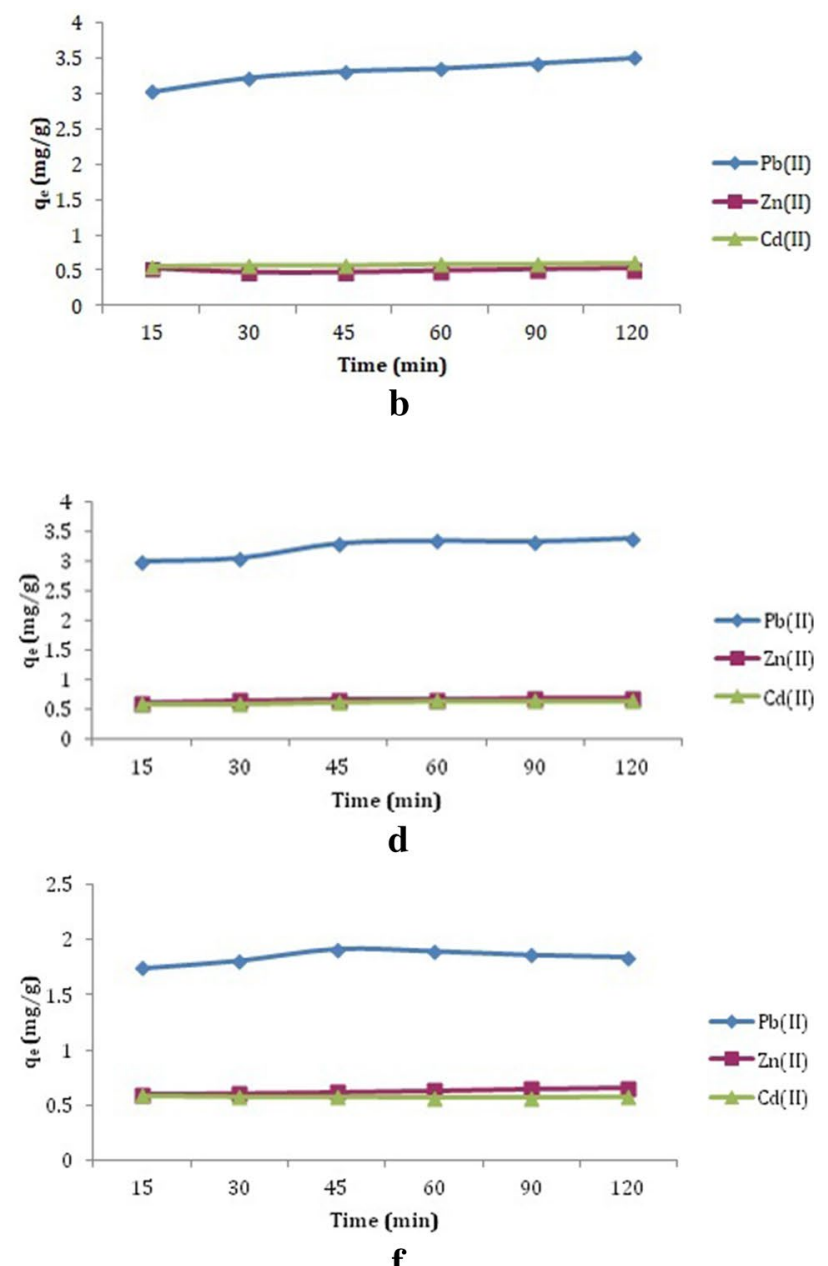

f
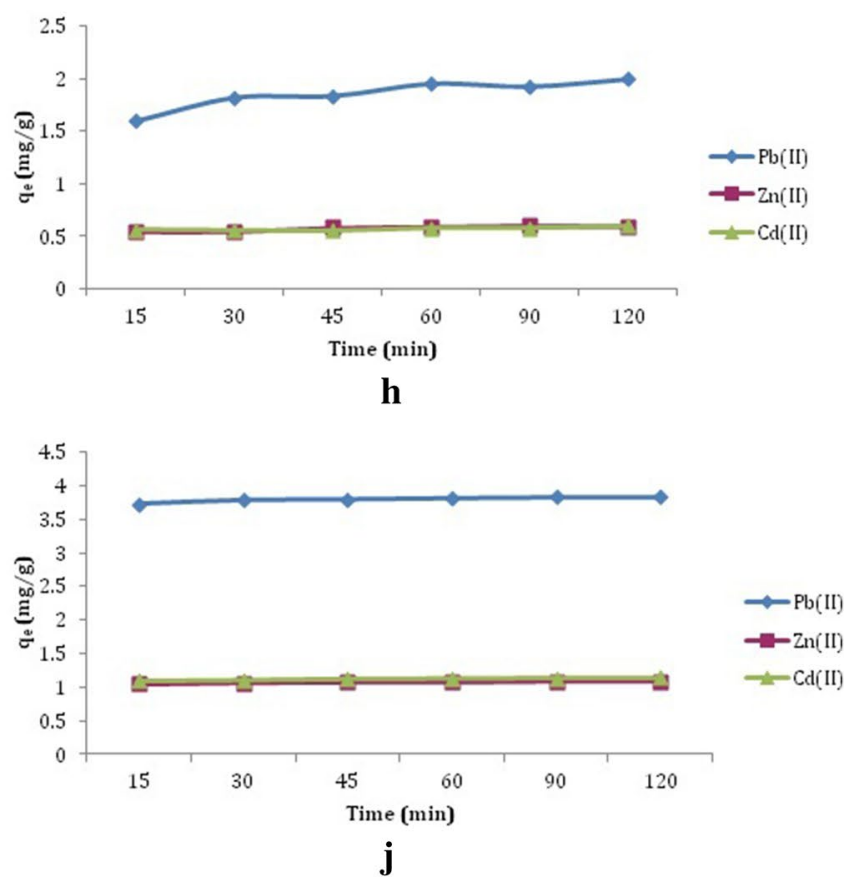

Figure 2. The contact time as a function of the (a) removal efficiency (E\%) of $\mathrm{Pb}(\mathrm{II}), \mathrm{Zn}$ (II) and $\mathrm{Cd}(\mathrm{II})$ ions by $\mathrm{ZSC}-\mathrm{H}_{2} \mathrm{SO}_{4}$; (b) the amount of biosorbed $\mathrm{Pb}(\mathrm{II}), \mathrm{Zn}(\mathrm{II})$ and $\mathrm{Cd}(\mathrm{II})$ ions per gram of $\mathrm{ZSC}_{2} \mathrm{H}_{2} \mathrm{SO}_{4}$; (c) the removal efficiency (E\%) of $\mathrm{Pb}(\mathrm{II}), \mathrm{Zn}$ (II) and $\mathrm{Cd}(\mathrm{II})$ ions by $\mathrm{ZSC}$-citric acid; (d) the amount of biosorbed $\mathrm{Pb}(\mathrm{II}), \mathrm{Zn}(\mathrm{II})$ and $\mathrm{Cd}(\mathrm{II})$ ions per gram of $\mathrm{ZSC}$-citric acid; (e) the removal efficiency(E\%) of $\mathrm{Pb}(\mathrm{II}), \mathrm{Zn}(\mathrm{II})$ and $\mathrm{Cd}(\mathrm{II})$ ions by $\mathrm{ZSC}-\mathrm{HCl}$; (f) the amount of biosorbed $\mathrm{Pb}(\mathrm{II}), \mathrm{Zn}(\mathrm{II})$ and $\mathrm{Cd}(\mathrm{II})$ ions per gram of ZSC-HCl; (g) the removal efficiency (E\%) of $\mathrm{Pb}(\mathrm{II}), \mathrm{Zn}(\mathrm{II})$ and $\mathrm{Cd}(\mathrm{II})$ ions by $\mathrm{ZSC}-\mathrm{H}_{2} \mathrm{O}_{2}$; (h) the amount of biosorbed $\mathrm{Pb}(\mathrm{II})$, $\mathrm{Zn}(\mathrm{II})$ and $\mathrm{Cd}(\mathrm{II})$ ions per gram of $\mathrm{ZSC}-\mathrm{H}_{2} \mathrm{O}_{2}$; (i) the removal efficiency(E\%) of $\mathrm{Pb}(\mathrm{II}), \mathrm{Zn}(\mathrm{II})$ and $\mathrm{Cd}(\mathrm{II})$ ions by $\mathrm{ZSC}-\mathrm{KOH}$ and (j) the amount of biosorbed $\mathrm{Pb}(\mathrm{II}), \mathrm{Zn}(\mathrm{II})$ and $\mathrm{Cd}(\mathrm{II})$ ions per gram of $\mathrm{ZSC}-\mathrm{KOH}$. 


\begin{tabular}{|l|l|l|l|}
\hline \multirow{2}{*}{ Biosorbent } & \multicolumn{3}{|l|}{$\% \mathbf{E}$} \\
\cline { 2 - 4 } & $\mathbf{P b}(\mathrm{II})$ & $\mathbf{Z n}(\mathrm{II})$ & $\mathbf{C d}(\mathrm{II})$ \\
\hline Raw ZSC & 71.43 & 41.84 & 39.25 \\
\hline $\mathrm{ZSC}-\mathrm{HCl}$ & 48.45 & 50.30 & 45.37 \\
\hline ZSC- $\mathrm{H}_{2} \mathrm{O}_{2}$ & 49.98 & 47.45 & 46.42 \\
\hline ZSC- $\mathrm{H}_{2} \mathrm{SO}_{4}$ & 85.96 & 39.61 & 47.45 \\
\hline ZSC-citric acid & 85.71 & 53.33 & 51.80 \\
\hline ZSC-KOH & 97.88 & 85.80 & 90.56 \\
\hline
\end{tabular}

Table 1. The biosorption process for the $\mathrm{Pb}(\mathrm{II}), \mathrm{Zn}(\mathrm{II})$ and $\mathrm{Cd}(\mathrm{II})$ ions by raw and modified $\mathrm{ZSCs}$ at equilibrium time.

1230,1134 and $1464-1610 \mathrm{~cm}^{-1}$, which are related to the changes in the vibrations of C-O and -COO-functional groups. This means that chelating $\mathrm{Pb}(\mathrm{II}), \mathrm{Zn}(\mathrm{II})$ and $\mathrm{Cd}(\mathrm{II})$ ions by $\mathrm{ZSC}$ may be attributed to the phenolic groups of the lignin and/or to the carboxyl groups contained in the $\mathrm{ZSCs}{ }^{23}$. The changes in the band at $3356 \mathrm{~cm}^{-1}$ means that the hydroxyl group is also involved in the metal ion biosorption ${ }^{49}$. For ZSC-KOH, the shift of the $\mathrm{C}=\mathrm{O}$ of carboxyl groups from 1705 to $1730 \mathrm{~cm}^{-1}$ is an indication for the metal coordination by ZSCs which is in a good agreement with the previous findings ${ }^{50}$.

Biosorption of $\mathrm{Pb}(\mathrm{II}), \mathrm{Zn}(\mathrm{II})$ and $\mathrm{Cd}(\mathrm{II})$ by chemically modified ZSCs. Effect of contact time for $\mathrm{Pb}(\mathrm{II}), \mathrm{Zn}(\mathrm{II})$ and Cd(II) removal by chemically modified ZSCs. The effect of contact time was studied for the five different chemically modified ZSCs: Modified by $\mathrm{H}_{2} \mathrm{SO}_{4}$, citric acid, $\mathrm{HCl}, \mathrm{H}_{2} \mathrm{O}_{2}$ and $\mathrm{KOH}$, at the studied time intervals of $15,30,45,60,90,120 \mathrm{~min}$, using $0.2 \mathrm{~g}$ of ZSCs with a size of $250 \mu \mathrm{m}$, and initial metal ion concentration of $31.27 \mathrm{mg} / \mathrm{L}$ for $\mathrm{Pb}(\mathrm{II})$ and $10 \mathrm{mg} / \mathrm{L}$ for $\mathrm{Zn}$ (II) and $\mathrm{Cd}$ (II) ion solution at a $\mathrm{pH}$ of 6 (Fig. 2a-j).

The removal percentage (\%E) of metal ions by modifying ZSCs was rapid initially, then increased slightly with contact time until reaching equilibrium. The equilibrium time was attained at $60 \mathrm{~min}$ in all cases. The biosorption capacity also slightly increased with time until it reached equilibrium. There was no difference between raw and modified ZSCs in terms of the effect of time on. A comparison between the removal of $\mathrm{Pb}$ (II), $\mathrm{Zn}$ (II) and Cd(II) by raw and modified ZSCs at equilibrium is shown in Table 1.

From the results shown in Table 1, it was observed that the modification enhanced the process of metal removal in all cases except for the removal of $\mathrm{Pb}(\mathrm{II})$ ions by $\mathrm{HCl}$ and $\mathrm{H}_{2} \mathrm{O}_{2}$-modified $\mathrm{ZSCs}$, and the removal of $\mathrm{Zn}$ (II) by $\mathrm{H}_{2} \mathrm{SO}_{4}$-modified ZSCs. These had a negative effect on the efficiency of removal. The enhancement of $\mathrm{Pb}(\mathrm{II})$ removal followed the order $\mathrm{ZSC}-\mathrm{KOH}>\mathrm{ZSC}-\mathrm{H}_{2} \mathrm{SO}_{4}<\mathrm{ZSC}$-citric acid. $\mathrm{Zn}$ (II) ion removal followed the order ZSC-KOH $>$ ZSC-citric acid $>$ ZSC-HCL $<\mathrm{ZSC}-\mathrm{H}_{2} \mathrm{O}_{2}$. Finally, the $\mathrm{Cd}(\mathrm{II})$ removal trend was ZSC- $\mathrm{KOH}<\mathrm{ZSC}$-citric acid $<\mathrm{ZSC}-\mathrm{H}_{2} \mathrm{SO}_{4}<\mathrm{ZSC}-\mathrm{H}_{2} \mathrm{O}_{2}<\mathrm{ZSC}-\mathrm{HCl}$. The modified ZSCs by KOH gave the most remarkable enhancement of removal capacity in all cases. This may be because alkali modification can increase the biosorption capacity by removing the materials that block the binding sites, such as protein and lipids ${ }^{51}$. Potassium hydroxide is a good reagent for the conversion of the ester groups to carboxylate and alcohol groups, which is favorable for cationic metal attraction ${ }^{52,53}$. Acidic modification also can increase the biosorbent surface area and porosity by eliminating the impurities, leading to an enhanced biosorption capacit ${ }^{54,55}$. Acidic modification also induces hydrolysis of the biosorbent functional groups and raises the anionic binding sites for cationic metals ${ }^{51}$.

Biosorption isotherm for Pb(II), Zn(II) and Cd(II) by chemically modified ZSCs. The Langmuir isotherm model was applied to calculate the maximum adsorption capacity related to the complete monolayer formation on the surface of modified ZSCs. The data were obtained using an initial metal ion concentration range of 2.5$31.27 \mathrm{mg} / \mathrm{L}$, with a solution with a $\mathrm{pH}$ of 6 and $0.2 \mathrm{~g}$ of chemically modified ZSCs with a size of $250 \mu \mathrm{m}$ that was shaken for $60 \mathrm{~min}$.

Linearity plots, as presented in Fig. 3a-o, illustrate that the Langmuir model was acceptable to represent the biosorption isotherm. Table 2 shows that the highest value of the maximum adsorption capacity on the modified ZSCs for $\mathrm{Pb}(\mathrm{II})$ was $9.06 \mathrm{mg} / \mathrm{g}$ and $4.19 \mathrm{mg} / \mathrm{g}$ for $\mathrm{Zn}(\mathrm{II})$ obtained by using ZSC-citric acid, while for Cd(II), it was $5.38 \mathrm{mg} / \mathrm{g}$ obtained by using $\mathrm{ZSC}-\mathrm{H}_{2} \mathrm{O}_{2}$.

The Langmuir isotherm characteristics can be described by the equilibrium parameter $\left(\mathrm{R}_{\mathrm{L}}\right)^{46}$ :

$$
R_{L}=\frac{1}{\left(1+K_{L} C_{0}\right)}
$$

where $K_{L}$ is the Langmuir constant and $C_{0}$ is the initial sorbate concentration $(\mathrm{mg} / \mathrm{L})$. An $R_{L}$ value that is $>0$ and $<1$ shows a favorable isotherm, if $R_{L}=1$, the isotherm would be linear, and if $R_{L}>1$ the isotherm would be unfavorable ${ }^{56}$. The $R_{L}$ values indicate that biosorption is favorable $\left(0<R_{L}<1\right)$.

Lead exhibits a high amount of biosorption and removal efficiency by both raw and chemically modified ZSCs. In fact, $\mathrm{Pb}$ (II) and $\mathrm{Zn}$ (II) were classified as borderline Lewis acids, and Cd(II) was classified as a soft acid according to hard-soft-acid-base theory. This theory explains the interaction between metal ions and ligands, as the hard acid tends to interact with a hard base, and soft acid with a soft base. Therefore, the increased binding affinity of $\mathrm{Pb}$ (II) and, in some cases, $\mathrm{Zn}$ (II) in comparison to $\mathrm{Cd}(\mathrm{II})$ ions can be attributed to their tendency to 

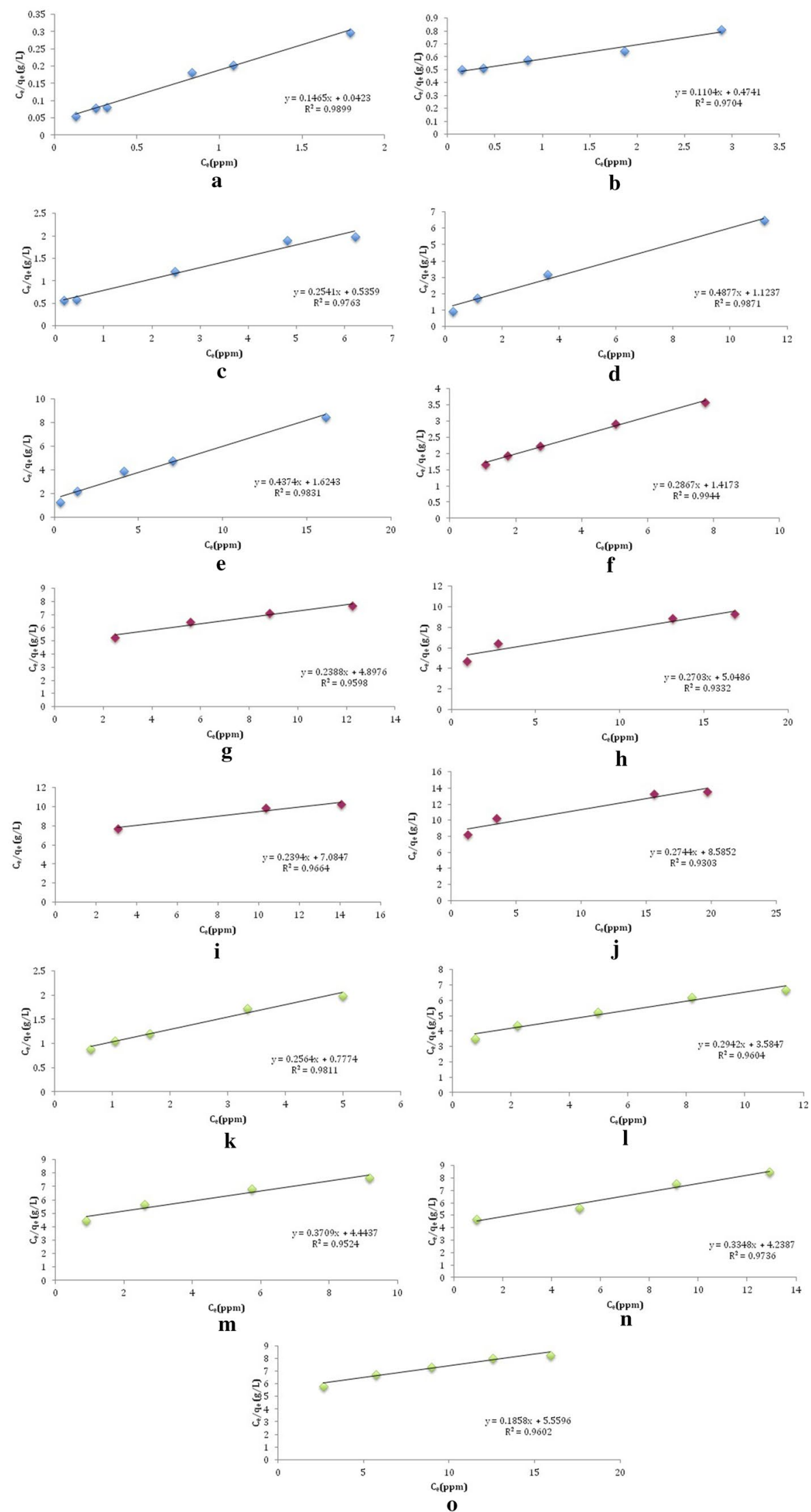

Figure 3. Langmuir isotherm for the biosorption of the following (a) $\mathrm{Pb}(\mathrm{II})$ onto $\mathrm{ZSC}-\mathrm{KOH}$; (b) $\mathrm{Pb}$ (II) onto ZSC-citric acid; (c) $\mathrm{Pb}$ (II) on to ZSC- $\mathrm{H}_{2} \mathrm{SO}_{4}$; (d) $\mathrm{Pb}$ (II) onto ZSC-HCl; (e) $\mathrm{Pb}$ (II) onto ZSC- $\mathrm{H}_{2} \mathrm{O}_{2}$; (f) $\mathrm{Zn}$ (II) onto ZSC-KOH; (g) $\mathrm{Zn}$ (II) onto ZSC-citric acid; (h) Zn(II) onto ZSC- $\mathrm{H}_{2} \mathrm{SO}_{4}$; (i) Zn(II) onto ZSC-HCl; (j) Zn(II) onto ZSC- $\mathrm{H}_{2} \mathrm{O}_{2}$; (k) Cd(II) onto ZSC-KOH; (l) Cd(II) onto ZSC-citric acid, (m) Cd(II) onto ZSC- $\mathrm{H}_{2} \mathrm{SO}_{4}$; (n) Cd(II) onto ZSC-HCl and (o) Cd(II) onto $\mathrm{ZSC}-\mathrm{H}_{2} \mathrm{O}_{2}$. 


\begin{tabular}{|l|l|l|l|l|}
\hline \multirow{2}{*}{ Metals ion, ZSC type } & \multicolumn{4}{|l|}{ Langmuir isotherm parameters } \\
\cline { 2 - 5 } & $\boldsymbol{q}_{\max }(\mathbf{m} \mathbf{g} / \mathbf{g})$ & $\boldsymbol{K}_{\boldsymbol{L}}(\mathbf{L} / \mathbf{g})$ & $\boldsymbol{R}^{\mathbf{2}}$ & $\boldsymbol{R}_{\boldsymbol{L}}$ \\
\hline $\mathrm{Pb}-\mathrm{ZSC}-\mathrm{KOH}$ & 6.83 & 3.46 & 0.9899 & 0.01 \\
\hline $\mathrm{Pb}-\mathrm{ZSC}-\mathrm{citric}$ acid & 9.06 & 0.23 & 0.9704 & 0.12 \\
\hline $\mathrm{Pb}-\mathrm{ZSC}-\mathrm{H}_{2} \mathrm{SO}_{4}$ & 3.94 & 0.47 & 0.9762 & 0.06 \\
\hline $\mathrm{Pb}-\mathrm{ZSC}-\mathrm{HCl}$ & 2.05 & 0.43 & 0.9871 & 0.07 \\
\hline $\mathrm{Pb}-\mathrm{ZSC}-\mathrm{H}_{2} \mathrm{O}_{2}$ & 2.29 & 0.27 & 0.9830 & 0.11 \\
\hline $\mathrm{Zn}-\mathrm{ZSC}-\mathrm{KOH}$ & 3.49 & 0.20 & 0.9944 & 0.14 \\
\hline $\mathrm{Zn}-\mathrm{ZSC}-\mathrm{citric}$ acid & 4.19 & 0.05 & 0.9597 & 0.40 \\
\hline $\mathrm{Zn}-\mathrm{ZSC}-\mathrm{H}_{2} \mathrm{SO}_{4}$ & 3.70 & 0.05 & 0.9332 & 0.37 \\
\hline $\mathrm{Zn}-\mathrm{ZSC}-\mathrm{HCl}$ & 4.18 & 0.03 & 0.9664 & 0.49 \\
\hline $\mathrm{Zn}-\mathrm{ZSC}-\mathrm{H}_{2} \mathrm{O}_{2}$ & 3.64 & 0.03 & 0.9303 & 0.50 \\
\hline $\mathrm{Cd}-\mathrm{ZSC}-\mathrm{KOH}$ & 3.90 & 0.33 & 0.9811 & 0.09 \\
\hline $\mathrm{Cd}-\mathrm{ZSC}-\mathrm{citric} \mathrm{acid}$ & 3.40 & 0.08 & 0.9604 & 0.28 \\
\hline $\mathrm{Cd}-\mathrm{ZSC}-\mathrm{H}_{2} \mathrm{SO}_{4}$ & 2.70 & 0.08 & 0.9523 & 0.28 \\
\hline $\mathrm{Cd}-\mathrm{ZSC}-\mathrm{HCl}$ & 2.99 & 0.08 & 0.9736 & 0.29 \\
\hline $\mathrm{Cd}-\mathrm{ZSC}-\mathrm{H}_{2} \mathrm{O}_{2}$ & 5.38 & 0.03 & 0.9601 & 0.49 \\
\hline
\end{tabular}

Table 2. Langmuir isotherm parameters for the biosorption of $\mathrm{Pb}(\mathrm{II}), \mathrm{Zn}$ (II) and $\mathrm{Cd}(\mathrm{II})$ onto the modified ZSCs.

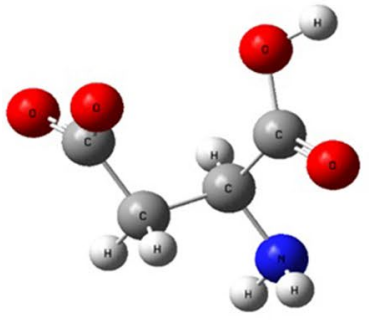

a

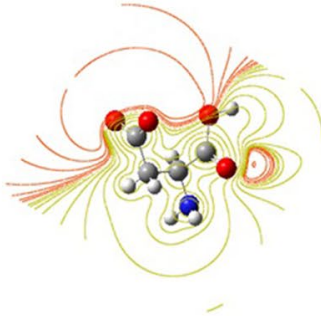

b

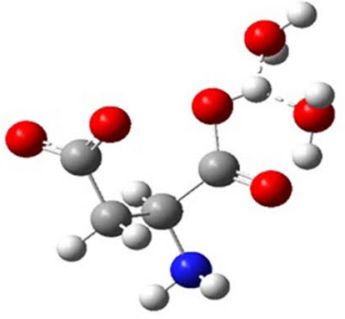

c

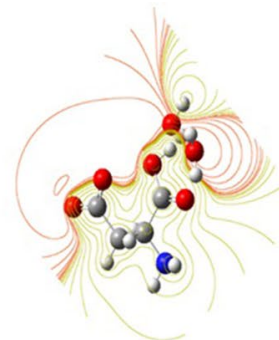

d

Figure 4. Model molecules for (a) aspartic acid as a model molecule for ZSCs, (b) ESP contour for aspartic acid, (c) di-hydrated aspartic acid, (d) ESP contour for di-hydrated aspartic acid.

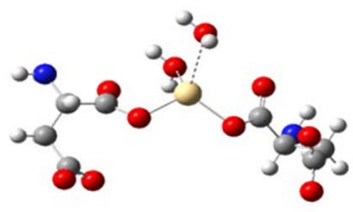

a

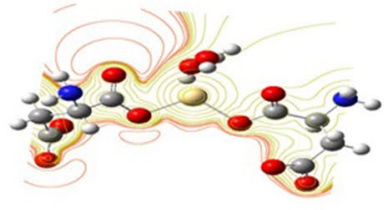

b

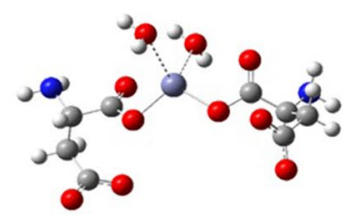

c

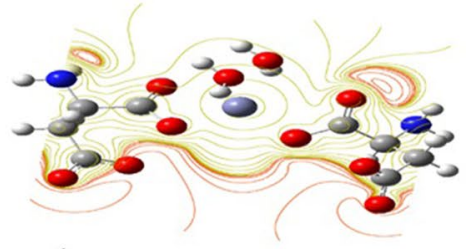

d

Figure 5. Model molecules for (a) di-hydrated cadmium interacting with two aspartic units, (b) ESP contour for di-hydrated cadmium interacting with two aspartic units, (c) di-hydrated zinc interacting with two aspartic units, (d) ESP contour for di-hydrated zinc interacting with two aspartic units.

bind with the hard carboxylate and hydroxyl base ${ }^{57}$. Heavy metal selectivity also referred to some of their metallic properties ${ }^{58}$. Lead has a larger ionic radius size (1.33 $\AA$ ) compared with $\mathrm{Zn}$ (II) $(0.74 \AA$ ) and Cd(II) (0.97 $\AA$ ), which means that $\mathrm{Pb}(\mathrm{II})$ ions are less hydrated than $\mathrm{Zn}(\mathrm{II})$ and $\mathrm{Cd}(\mathrm{II})^{59,60}$. It has also higher electronegativity, resulting in a harder Lewis acid than zinc and cadmium ${ }^{61}$. From the previously determined Langmuir constant $\mathrm{K}_{\mathrm{L}}$, it is observed that $\mathrm{Pb}(\mathrm{II})$ ions have more affinity to the raw and chemically modified ZSCs than $\mathrm{Zn}$ (II) and Cd(II) ions.

Mechanism of biosorption of $\mathrm{Pb}(\mathrm{II}), \mathrm{Zn}(\mathrm{II})$ and $\mathrm{Cd}(\mathrm{II})$ by chemically modified ZSCs. In order to understand the mechanism of interaction between ZSCs and the studied metals, density-functional theory (DFT) was conducted at DFT: B3LYP level with 6-31 $\mathrm{g}(\mathrm{d}, \mathrm{p})$ basis set.

Aspartic acid was proposed to simulate the ZSCs molecules. Therefore, the coordination of the metal with ZSCs could be the result of coordination with $\mathrm{COOH}$, which is typical for organic acids as well as amino acids 
with a protein structure. In this part, the coordination of $\mathrm{Cd}$ and $\mathrm{Zn}$ is attempted. The model molecules shown in Fig. 4 show that aspartic acid and its molecular ESP as a contour are described; then, the di-hydration of the acid is also described after the interaction with two water molecules, and subsequently the contour of ESP. The dependence on the ESP as a marker for reactivity was described earlier ${ }^{62-65}$. The red color is an indication of active sites, such that the active sites in Fig. $4 \mathrm{~b}-\mathrm{d}$ is more likely to occur around the carboxyl group as compared to the amide group.

Figure 5 demonstrates the model molecules for a) di-hydrated cadmium interacting with two aspartic units, and b) the ESP contour for di-hydrated cadmium interacting with two aspartic units. It is clear that Cd ions interacted weakly with two water molecules, then further interacted with two carboxyl groups of two aspartic units as a complex interaction. The contour of ESP shows an increase in the active site around the carboxyl with less activity around the amide. Another confirmation of the mechanism is conducted in the case of di-hydrated $\mathrm{Zn}$, as shown in Fig. 5, which shows the model molecules for c) di-hydrated zinc interacting with two aspartic units, and d) the ESP contour for di-hydrated zinc interacting with two aspartic units.

Zinc was also di-hydrated, then interacted with the carboxyl of two aspartic units through the hydrogen bonding as a complex interaction.

The ESP is also more likely to occur around the carboxyl group. As compared to the results of FTIR, the molecular modeling work suggested that the probability of the mediation of heavy metals with ZSCs is more likely to happen through the $\mathrm{COOH}$ of the amino acids.

The presented model describes the mechanism of interaction between the plant and the hydrated metals. Other efforts which describe the biosorption with Ziziphus could be found recently in the literature ${ }^{66-68}$. This work gave insight into another possibility for the plant to remediate other pollutants rather than HMs.

\section{Conclusions}

Green methods for controlling water pollution is very important as it is depending on natural resources. This route is minimizing the adverse impacts on the aquatic environment. For this purpose, the natural materials ZSCs were chemically modified by testing different alkaline and acidic chemicals. FTIR analysis indicated that the raw lignocellulosic ZSCs consisted of different oxygen-containing functional groups, allowing it to possibly link to the metal ions either by ion-exchanging or complexation. Alkali-modified ZSCs by KOH in comparison with the acidic ones was more effective and enhanced the ZSCs removal efficiency by increasing the carboxylate ions. The biosorption of $\mathrm{Pb}(\mathrm{II}), \mathrm{Zn}(\mathrm{II})$ and $\mathrm{Cd}(\mathrm{II})$ ions on the chemically modified ZSCs followed the Langmuir isotherm model. The highest value of the maximum adsorption capacity of the modified ZSCs for $\mathrm{Pb}$ (II) was $9.06 \mathrm{mg} / \mathrm{g}$, and $4.19 \mathrm{mg} / \mathrm{g}$ for $\mathrm{Zn}$ (II) as obtained by using ZSC-citric acid, while for Cd(II), the highest value was $5.38 \mathrm{mg} / \mathrm{g}$, obtained by using ZSC- $\mathrm{H}_{2} \mathrm{O}_{2}$. The chemically modified ZSCs can be used as an efficient biosorbent for heavy metals remediation from wastewater, as an eco-friendly and economic material which is more selective for $\mathrm{Pb}$ (II) removal. The molecular modeling study indicated that each metal is di-hydrated, then formed a stable complex with two amino acid units. Therefore, the mechanism of uptake is described as a complex state between the protein structure of the ZSCs and the hydrated heavy metals.

Received: 22 July 2020; Accepted: 29 October 2020

Published online: 25 November 2020

\section{References}

1. Vilaseca, M., Gutiérrez, M. C., López-Grimau, V., López-Mesas, M. \& Crespi, M. Biological treatment of a textile effluent after electrochemical oxidation of reactive dyes. Water Environ. Res. 82, 176-182 (2010).

2. Mahmood, Q., Mahnoor, A., Shahida, S., Tahir, M. \& Ali, S. Cadmium contamination in water and soil. In Cadmium Toxic (eds Hasanuzzaman, M. et al.) 141-161 (Elsevier, Amsterdam, Toler. Plants, 2018).

3. Wasi, S., Tabrez, S. \& Ahmad, M. Toxicological effects of major environmental pollutants: an overview. Environ. Monit. Assess. 185, 2585-2593 (2013).

4. Malik, A. Environmental challenge vis a vis opportunity: the case of water hyacinth. Environ. Int. 33, 122-138 (2007).

5. Asere, T. G., Stevens, C. V. \& Du Laing, G. Use of (modified) natural adsorbents for arsenic remediation: a review. Sci. Total Environ. 676, 706-720 (2019).

6. Shakoor, M. B. et al. Remediation of arsenic contaminated water using agricultural wastes as biosorbents. Crit. Rev. Environ. Sci. Technol. 46, 467-499 (2016).

7. Bilal, M., et al. Waste biomass adsorbents for copper removal from industrial wastewater-a review. J. Hazard. Mater. 263Pt 2, 322-333 (2013).

8. Lesmana, S. O., Febriana, N., Soetaredjo, F. E., Sunarso, J. \& Ismadji, S. Studies on potential applications of biomass for the separation of heavy metals from water and wastewater. Biochem. Eng. J. 44, 19-41 (2009).

9. Ofomaja, A. E. \& Ho, Y. S. Effect of pH on cadmium biosorption by coconut copra meal. J. Hazard. Mater. 139, 356-362 (2007).

10. Saied, S., Gebauer, J., Hammer, K. \& Buerkert, A. Ziziphus spina-christi (L.) willd: a multipurpose fruit tree. Genet. Resour. Crop Evol. 55, 929-937 (2008).

11. Omri, A. \& Benzina, M. Characterization of activated carbon prepared from a new raw lignocellulosic material: Ziziphus SpinaChristi seeds. J. Soc. Chim. Tunisie 14, 175-183 (2012).

12. Nazif, N.M. Phytoconstituents of Zizyphus spina-christi L. fruits and their antimicrobial activity. Food Chem. 76, 77-81 (2002).

13. Amoo, I. A. \& Atasie, V. N. Nutritional and functional properties of Tamarindus Indica Pulp and Zizyphus spina-christi fruit and seed. J. Food Agric. Environ. 10, 16-19 (2012).

14. Osman, M. A. \& Ahmed, M. A. Chemical and proximate composition of (Zizyphus spina-christi) Nabag Fruit. Nutr. Food Sci. 39, 70-75 (2009).

15. Ngah, W. S. W. \& Hanafiah, M. A. K. M. Removal of heavy metal ions from wastewater by chemically modified plant wastes as adsorbents: a review. Bioresour. Technol. 99, 3935-3948 (2008).

16. Gautam, R.K., Chattopadhyaya, M.C. \& Sharma, S.K. Biosorption of heavy metals: recent trends and challenges Ravindra. In Wastewater Reuse and Management; (Sharma, S.K., Sanghi, R., Eds).; Springer: Berlin, 305-322 (2013).

17. Park, D., Yun, Y.-S. \& Park, J. M. The past, present, and future trends of biosorption. Biotechnol. Bioprocess Eng. 15, 86-102 (2010). 
18. Won, S. W., Kotte, P., Wei, W., Lim, A. \& Yun, Y.-S. Biosorbents for recovery of precious metals. Bioresour. Technol. 160, 203-212 (2014).

19. Patel, S. Potential of fruit and vegetable wastes as novel biosorbents: summarizing the recent studies. Rev. Environ. Sci. Bio/Technol. 11, 365-380 (2012).

20. Volesky, B. Biosorption and me. Water Res. 41, 4017-4029 (2007).

21. Vijayaraghavan, K. \& Yun, Y. S. Bacterial biosorbents and biosorption. Biotechnol. Adv. 26, 266-291 (2008).

22. Acar, F. N. \& Eren, Z. Removal of $\mathrm{Cu}(\mathrm{II})$ ions by activated poplar sawdust (Samsun Clone) from aqueous solutions. J. Hazard. Mater. 137, 909-914 (2006).

23. Reddy, B. R., Mirghaffari, N. \& Gaballah, I. Removal and recycling of copper from aqueous solutions using treated Indian barks. Resour. Conserv. Recycl. 21, 227-245 (1997).

24. Su, P., Zhang, J., Tang, J. \& Zhang, C. Preparation of nitric acid modified powder activated carbon to remove trace amount of Ni(II) in aqueous solution. Water Sci. Technol. 80, 86-97 (2019).

25. Sciban, M., Klasnja, M. \& Skrbic, B. Modified softwood sawdust as adsorbent of heavy metal ions from water. J. Hazard. Mater. 136, 266-271 (2006).

26. Taty-Costodes, V. C., Fauduet, H., Porte, C. \& Delacroix, A. Removal of Cd(II) and Pb(II) ions, from aqueous solutions, by adsorption onto sawdust of Pinus sylvestris. J. Hazard. Mater. 105, 121-142 (2003).

27. Gupta, V. K., Jain, C. K., Ali, I., Sharma, M. \& Saini, V. K. Removal of cadmium and nickel from wastewater using bagasse fly ash-a sugar industry waste. Water Res. 37, 4038-4044 (2003).

28. Polatoğlu, I. \& Karataş, D. Modeling of molecular interaction between catechol and tyrosinase by DFT. J. Mol. Struct. 1202, 127192 (2020).

29. Omar, A., Ezzat, H., Elhaes, H. \& Ibrahim, M. A. Molecular modeling analyses for modified biopolymers. Biointerface Res. Appl. Chem. 11(1), 7847-7859 (2021).

30. Badry, R. et al. Spectroscopic and thermal analyses for the effect of acetic acid on the plasticized sodium carboxymethyl cellulose. J. Mol. Struct. 1224, 129013 (2021).

31. Menazea, A. A. et al. Chitosan/graphene oxide composite as an effective removal of $\mathrm{Ni}, \mathrm{Cu}, \mathrm{As}, \mathrm{Cd}$ and $\mathrm{Pb}$ from wastewater. Comput. Theor. Chem. 1189, 112980 (2020).

32. Al-Bagawi, A. H., Bayoumy, A. M. \& Ibrahim, M. A. Molecular modeling analyses for graphene functionalized with $\mathrm{Fe}_{3} \mathrm{O}_{4}$ and $\mathrm{NiO}$. Heliyon 6(7), e04456 (2020).

33. Assirey, E. A., Sirry, S. M., Burkani, H. A. \& Ibrahim, M. Biosorption of zinc(II) and cadmium(II) using Ziziphus spina stones. J. Comput. Theor. Nanosci. 15, 3102-3108 (2018).

34. Rice, E. W., Baird, R. B., Eaton, A. D. \& Clesceri, L. S. Standard Methods for the Examination of Water and Wastewater 23rd edn. (American Public Health Association (APHA), Washington, DC, 2017).

35. Zhang, B. et al. Biosorption characteristics of Bacillus gibsonii S-2 waste biomass for removal of lead (II) from aqueous solution. Environ. Sci. Pollut. Res. Int. 20, 1367-1373 (2013).

36. Langmuir, I. The adsorption of gases on plane surfaces of glass, mica and platinum. J. Am. Chem. Soc. 40, 1361-1403 (1918).

37. Frisch, M. et al. Gaussian 09, revision C.01 (Gaussian, Inc., Wallingford, 2009).

38. Becke, A. D. Density-functional thermochemistry-III: the role of exact exchange. Chem. Phys. 98, 5648 (1993).

39. Lee, C., Yang, W. \& Parr, R. G. Development of the Colle-Salvetti correlation-energy formula into a functional of the electron density. Phys. Rev. B 37, 785 (1988).

40. Miehlich, B., Savin, A., Stoll, H. \& Preuss, H. Results obtained with the correlation energy density functionals of Becke and Lee Yang and Parr. Chem. Phys. Lett. 157, 200-206 (1989).

41. Jin, Y., Zhang, Y., Lü, Q. \& Cheng, X. Biosorption of methylene blue by chemically modified cellulose waste. J. Wuhan Univ. Technol. Sci. Ed. 29, 817-823 (2014).

42. Calero, M., Pérez, A., Blázquez, G., Ronda, A. \& Martín-Lara, M. A. Characterization of chemically modified biosorbents from olive tree pruning for the biosorption of lead. Ecol. Eng. 58, 344-354 (2013).

43. Abdolali, A. et al. Characterization of a multi-metal binding biosorbent: chemical modification and desorption studies. Bioresour. Technol. 193, 477-487 (2015).

44. Brigida, A. I. S., Calado, V. M. A., Goncalves, L. R. B. \& Coelho, M. A. Z. Effect of chemical treatments on properties of green coconut fiber. Carbohydr. Polym. 79, 832-838 (2010).

45. Herrera-Franco, P. J. \& Valadez-Gonzalez, A. A. Study of the mechanical properties of short natural-fiber reinforced composites. Compos. Part B Eng. 36, 597-608 (2005).

46. Mao, J., Won, S. W., Choi, S. B., Lee, M. W. \& Yun, Y. S. Surface modification of the Corynebacterium Glutamicum biomass to increase carboxyl binding site for basic dye molecules. Biochem. Eng. J. 46, 1-6 (2009).

47. Ramana, D. K. V., Reddy, K. D. H., Kumar, B. N., Harinath, Y. \& Seshaiah, K. Removal of nickel from aqueous solutions by citric acid modified Ceiba Pentandra Hulls: equilibrium and kinetic studies. Can. J. Chem. Eng. 90, 111-119 (2012).

48. Martín-Lara, M. A., Pagnanelli, F., Mainelli, S., Calero, M. \& Toro, L. Chemical treatment of olive Pomace: effect on acid-basic properties and metal biosorption capacity. J. Hazard. Mater. 2012(156), 448-457 (2012).

49. Shadreck, M., Chigondo, F., Shumba, M., Nyamunda, B. C. \& Edith, S. Removal of chromium (VI) from aqueous solution using chemically modified orange (Citrus Cinensis) peel. IOSR J. Appl. Chem. 6, 66-75 (2013).

50. Olu-owolabi, B. I., Oputu, O. U., Adebowale, K. O., Ogonsolu, O. \& Olujimi, O. O. Biosorption of $\mathrm{Cd}^{2+}$ and $\mathrm{Pb}^{2+}$ ions onto mango stone and cocoa pod waste: kinetic and equilibrium studies. Sci. Res. Essays 7, 1614-1629 (2012).

51. Adhiambo, O.R., Lusweti, K.J. \& Morang'a, G.Z. Biosorption of $\mathrm{Pb}^{2+}$ and $\mathrm{Cr}^{2+}$ Using Moringa oleifera and their adsorption isotherms. Sci. J. Anal. Chem., 3, 100-108 (2015).

52. Ofomaja, A. E., Naidoo, E. B. \& Modise, S. J. Biosorption of copper(II) and lead(II) onto potassium hydroxide treated pine cone powder. J. Environ. Manag. 91, 1674-1685 (2010).

53. Min, S. H., Han, J. S., Shin, E. W. \& Park, J. K. Improvement of cadmium ion removal by base treatment of juniper fiber. Water Res. 38, 1289-1295 (2004).

54. Kapoor, A. \& Viraraghavan, T. Heavy metal biosorption sites in Aspergillus Niger. Bioresour. Technol. 61, 221-227 (1997).

55. Vijayaraghavan, K. \& Yun, Y. S. Utilization of fermentation waste (Corynebacterium glutamicum) for biosorption of reactive black 5 from aqueous solution. J. Hazard. Mater. 141, 45-52 (2007).

56. Alslaibi, T.M., Abustan, I., Ahmad, M.A. \& Abu Foul, A. Comparative studies on the olive stone activated carbon adsorption of $\mathrm{Zn}^{2+}, \mathrm{Ni}^{2+}$, and $\mathrm{Cd}^{2+}$ from synthetic wastewater. Desalin. Water Treat., 54, 166-177 (2015).

57. Papageorgiou, S. K. et al. Heavy metal sorption by calcium alginate beads from Laminaria digitata. J. Hazard. Mater. 137, 1765-1772 (2006).

58. Usman, A. R. A. The relative adsorption selectivities of $\mathrm{Pb}, \mathrm{Cu}, \mathrm{Zn}, \mathrm{Cd}$ and $\mathrm{Ni}$ by soils developed on shale in New Valley Egypt. Geoderma 144, 334-343 (2008).

59. Gilbert, U. A., Emmanuel, I. U., Adebanjo, A. A. \& Olalere, G. A. Biosorptive removal of $\mathrm{Pb}^{2+}$ and $\mathrm{Cd}^{2+}$ onto novel biosorbent: defatted Carica papaya seeds. Biomass Bioenergy 35, 2517-2525 (2011).

60. Jimoh, T. O., Yisa, J., Ajai, A. I. \& Musa, A. Kinetics and thermodynamics studies of the biosorption of $\mathrm{Pb}(\mathrm{II}), \mathrm{Cd}(\mathrm{II})$ and $\mathrm{Zn}$ (II) ions from aqueous solution by sweet orange (Citrus sinensis) seeds. Int. J. Mod. Chem. 4, 19-37 (2013). 
61. Shawabkeh, R., Al-Harahsheh, A., Hami, M. \& Khlaifat, A. Conversion of oil shale ash into zeolite for cadmium and lead removal from wastewater. Fuel 83, 981-985 (2004).

62. Politzer, P. \& Murray, J.S. Molecular electrostatic potentials. In Concepts and Applications, (Theoretical and Computational Chemistry), 1st edn.; Murray, J.S., Sen, K., Eds.; Elsevier: Amsterdam, 3, 649-660 (1996).

63. Ibrahim, A., Elhaes, H., Meng, F. \& Ibrahim, M. Effect of hydration on the physical properties of glucose. Biointerface Res. Appl. Chem. 8, 4114-4118 (2019).

64. Ibrahim, A., Elhaes, H., Ibrahim, M., Yahia, I. S. \& Zahran, H. Y. Molecular modeling analyses for polyvinylidene X (X=F, Cl, Br and I). Biointerface Res. Appl. Chem. 9, 3890-3893 (2019).

65. Ezzat, H. et al. Mapping the molecular electrostatic potential of carbon nanotubes. Biointerface Res. Appl. Chem. 8, 3539-3542 (2018).

66. Msaada, A. et al. Industrial wastewater decolorization by activated carbon from Ziziphus lotus. Desalin. Water Treat. 126, 296-305 (2018).

67. Msaad, A., Belbahloul, M., El Hajjaji, S. \& Zouhri, A. Comparison of novel Ziziphus lotus adsorbent and industrial carbon on methylene blue removal from aqueous solutions. Water Sci. Technol. 78(10), 2055-2063 (2018).

68. Msaad, A., Belbahloul, M., El Hajjaji, S., Zouhri, A. Synthesis of $\mathrm{H}_{3} \mathrm{PO}_{4}$ activated carbon from Ziziphus lotus (Z. mauritiana) leaves: optimization using RSM and cationic dye adsorption. Desalin. Water Treat. 153, 288-299 (2019).

\section{Acknowledgements}

This work received fund form King Abdulaziz City of Science and Technology (Project code: P-S-322-36).

\section{Author contributions}

We share equally the work, all authors are contributing during the work E.A.A. assign the point, supervise the work write the paper and the discussion. S.M.S. conduct experimental work, write the paper, discuss the results. H.A.B. conduct experimental work, write the paper, discuss the results. M.I. correlate the results and conduct molecular modeling.

\section{Competing interests}

The authors declare no competing interests.

\section{Additional information}

Correspondence and requests for materials should be addressed to E.A.A. or M.A.I.

Reprints and permissions information is available at www.nature.com/reprints.

Publisher's note Springer Nature remains neutral with regard to jurisdictional claims in published maps and institutional affiliations.

Open Access This article is licensed under a Creative Commons Attribution 4.0 International License, which permits use, sharing, adaptation, distribution and reproduction in any medium or format, as long as you give appropriate credit to the original author(s) and the source, provide a link to the Creative Commons licence, and indicate if changes were made. The images or other third party material in this article are included in the article's Creative Commons licence, unless indicated otherwise in a credit line to the material. If material is not included in the article's Creative Commons licence and your intended use is not permitted by statutory regulation or exceeds the permitted use, you will need to obtain permission directly from the copyright holder. To view a copy of this licence, visit http://creativecommons.org/licenses/by/4.0/.

(C) The Author(s) 2020 